\section{CIVILIAN CONTRIBUTION TO EDUCATION IN H.M. FORCES}

$\mathrm{T}$ HE report of the Central Advisory Council for Adult Education in H.M. Forces for the six months ending September 1944 presents further evidence of the remarkable growth of education in the Services and of the inestimable contribution made by civilians. During the period under review 59,023 single lectures, 2,955 short courses (average number of meetings 5), 2,358 classes (average number of meetings 9), and 348 intensive schools, leader's courses and conferences, are known to have been arranged through the agency of regional committees. Besides these activities, other classes were arranged by local education authorities direct with the Services, while many other informal meetings are difficult to represent statistically. By far the greatest quantity of work was done for the Army, especially the AntiAircraft Command; but a considerable amount was done for the Navy, the Royal Air Force, and the United States Forces. Since much of the educational work is co-educational, it is difficult to show how much advantage was taken by the Women's Services of regional committee facilities; but the amount of all-women activities was approximately one-sixth of the whole.

Analysis of the subjects taken shows that, as usual, current affairs accounted for the greatest demand in lectures and short courses. Of the classes, handicrafts and languages were most popular. An illuminating comment on the work as a whole is that the number of handicraft classes continued to show substantial increases, despite the all-round tightening in the supply of tools and materials. There was an increased demand for single lectures on science topics, and a considerable rise in the number of classes in 'nonvocational' science. This interest in science was undoubtedly stimulated by those regional committees which made deliberate attempts to provide facilities and to make them widely known. The response was particularly encouraging where it was possible to cater for voluntary audiences. It is unlikely, however, that any great demand for science will be forthcoming until there are far more science lecturers and teachers who will pay at least as much attention to the presentation of their subjects as to their content.

In music, the demand continued to be for general talks and discussions, and piano and gramophone lecture-recitals, although many analytical lectures and classes in the history and appreciation of music were also held. Wherever suitable lecturers were available, the demands for drama were more than enough to keep them fully occupied. A number of play-reading circles and speech-training classes were formed, while drama festivals were organized and assisted. Much was also accomplished at music and drama week-end schools, which are extremely popular as a voluntary activity with members of both men's and women's Services. On the arts side, the main task was in the raising and maintaining of standards, the development of creative work, and the widening of the range of crafts practised on many sites, rather than the expansion of pioneer work. Among the various informal activities undertaken, a gardening advisory service, which was arranged by one regional committee, invites comment. This ser- vice supplied notes on food production, as well as personal advice. 95,000 plants raised in the university botanic gardens were distributed to units taking advantage of the advisory scheme last season. These included vegetables, shrubs, herbaceous plants, alpines and annuals, in addition to gift boxes of American vegetable seeds. Figures of produce yields are not available; but the quality of cultivation was said to be high.

Of the 348 intensive schools provided by the regional committees, 101 were residential and more would have been if accommodation had been available. Towards the end of the summer, several committees planned to provide residential hostels to be used solely for their Service work, and, during the autumn, one hostel in England and another in Scotland were opened. It would be impossible here to describe adequately the different courses held; but the following may be regarded as illustrative examples. One regional committee arranged a series of seven voluntary week-end courses in music, drama, the film, art, science, literature, and the art of living. About sixty students attended each week-end, and there were waiting lists of up to a hundred for each course. To assist in the training of teachers for the Release Period Education Scheme (Nature, 154, 525 ; 1944), five regional committees serving an Army Command arranged a series of courses, each of a fortnight in duration, in science, history, geography, literature and economics.

Perhaps the most astonishing feature of the report as a whole is that it was possible to carry on so many educational activities during one of the major climacterics of the War. For many of the committees, the period was a difficult one owing to the uncertainty of the demand from week to week. The slight decline in the number of single lectures and short courses was more than counterbalanced by the increase in the total number of classes. In many ways this "was an advantage, and one committee reported that: "Education in the Services has probably approached more closely to civilian peacetime adult education than before. Previously we had to maintain an uneasy balance between keeping the units amused and encouraging them to think for themselves, and since the lecturers who can do both are rare, the sheer volume of demand in the past obliged us to use (more frequently than we liked) the 'popular' lecturer for pioneer work. With a smaller demand, we have been able to use lecturers of a considerably higher standard". The Central Advisory Council, the regional committees, and all the civilians who have helped in this richly consequential work deserve the warmest commendations of a democratic country.

Service men and women at home have shown their gratitude for the work done for them by these civilians, and, to a lesser extent, those serving abroad are now being given an opportunity to share in the facilities. Recently, a scheme was started whereby prominent civilians make tours abroad to lecture to H.M. Forces. Some of these visits have been concluded with memorable results. It is pleasant to note that, during the next few months, some well-known men of science are to take part in this overseas' lecturers scheme. With lessening demands on them for purposes of war, perhaps more of them will be freed to take part in this valuable work.

The report was issued by the Central Advisory Council for Education in H.M. Forces (secretary, Dr. Basil A. Yeaxley) at Rewley House, Oxford. 